\title{
PELUANG DAN KENDALA \\ PENERAPAN TUGAS WILAYAH AL-HISBAH SEBAGAI PENGAWAS PASAR DI PROVINSI ACEH
}

\author{
Hidayatina dan Sri Hananan \\ Fakultas Ekonomi Bisnis Islam IAIN Lhokseumawe \\ J1. Medan Banda Aceh Km. 275, No. 1 Bukit Rata-Alue Awe, Lhokseumawe \\ e-mail: hidayatinatina@ymail.com
}

\begin{abstract}
This study aims to analyze the opportunities and constraints in the implementation of the tasks of Wilayatul Hisbah as a market watchdog in Aceh Province. This research uses qualitative method (naturalistic paradigm) with case approach. The result of this research is the opportunity to apply market supervision as part of the task of Wilayatul Hisbah in Aceb by revising the qanun related to the implementation of the WH duties in Aceh. While the obstacles faced are the limitations of Qanun, the lack of understanding of community law, the presence of other market watchdog institutions, and the increasing lack of attention to the economic welfare of WH officers.
\end{abstract}

Kata kunci: wilayatul hisbah, pengawas pasar, Qanun Aceh

\section{PENDAHULUAN}

A l-hisbah merupakan institusi pemerintah yang bertujuan untuk mewujudkan apa yang disebut dengan humanisasi dan liberalisasi sebagaimana yang terlihat dalam ajaran agama Islam tentang amr alma'ruf wa nahy 'an al-munkar. Ia dimaksudkan sebagai lembaga yang menganjurkan pada kebaikan dan mencegah kemungkaran dalam wilayah yang tak bisa diawasi oleh institusi biasa. Lembaga ini dalam ruang lingkup ekonomi Islam juga berperan sebagai lembaga pengawas pasar ekonomi yang memonitor perilaku para pelaku ekonomi agar berjalan sesuai dengan koridor dan mekanisme yang menjadi tujuan-tujuan syariah, yaitu kemaslahatan umum yang ditujukan untuk memelihara agama, diri, akal, keturunan dan harta. Sebagai lembaga pengawas ekonomi alhisbah menjamin tidak terjadinya monopoli, pelanggaran aturan moral dalam pasar, hak konsumen, keamanan, dan kesehatan kehidupan ekonomi. (Ikhwan Hamdani, 2003: 96)

Seiring pemberlakuan UndangUndang Republik Indonesia Nomor 44 tahun 1999 tentang penyelenggaraan keistimewaan provinsi daerah istimewa Aceh dan UU Republik Indonesia No 18 tahun 2001 tentang otonomi Khusus bagi provinsi Nanggroe Aceh Darussalam serta PERDA Nomor 5 tahun 2000 tentang pelaksanaan Syariat Islam maka terbentuklah sebuah lembaga Wilayatul Hisbah yang dikuatkan dengan Qanun Nomor 11 tahun 2004 tentang organisasi dan tata kerja Wilayatul Hisbah yang keberadaannya diharapkan untuk mengawasi pelaksanaan Syari'at Islam di Nanggroe Aceh Darussalam. 
Jika ditelusuri lebih jauh tentang wilayatul hisbah dalam kajian Islam, sejak zaman pemerintahan Rasulullah SAW, sebenarnya tugas wilayatul hisbah mencakup seluruh aktivitas yang berhubungan dengan penegakan syariat Islam, sebagaimana yang dijelaskan oleh Ibnu Khaldun, dia mendefinisikan kalimat hisbah itu dalam Muqaddimah-nya: "Hisbah adalah termasuk kewajiban agama yang dalam kategori amar ma'ruf dan nahi munkar". "Sesungguhnya al-hisbah ialah setiap ma' ruf yang ditinggalkan dan setiap munkar yang dikerjakan". Amar ma'ruf dan nahi munkar adalah kewajiban dari Allah SWT dalam al-Qur'an. Di dalamnya Allah banyak memuji orang yang melakukan amar ma'ruf dan nahi munkar. (Muhammad, 2009: 45)

Berdasarkan definisi hisbah yang dikemukakan Ibnu Khaldun di atas, maka pengawasan terhadap aktivitas pasar ekonomi juga termasuk menjadi bagian dari tugas dan peran dari wilayatul hisbah. Namun, tugas dan peran Wilayatul Hisbah(disingkat dengan $\mathrm{WH}$ ) yang ada di Aceh yang mengacu pada Qanun Nomor 11 tahun 2004, hanya sebatas pengawasan terhadap pelanggaran syariat terkait persoalan khalwat, maisir, judi, khamar dan pelanggaran syariat lainnya.

Perekonomian merupakan salah satu pondasi dasar untuk dapat terbangunnya sebuah pemerintahan yang berorientasi kepada kesejahteraan masyarakatnya. Namun persoalan perekonomian yang muncul dalam pemerintahan tersebut, merupakan permasalahan yang sangat rumit untuk bisa diselesaikan. Begitu juga halnya persoalan ekonomi yang dihadapi oleh pemerintahan provinsi Aceh, merupakan salah satu permasalahan yang sangat komplek apalagi dengan terjadinya gempa bumi dan gelombang tsunami tanggal 26 Desember 2004.

Jika dilihat kondisi ekonomi Aceh, angka kemiskinan mencapai 18\% dari jumlah penduduknya, dimana angka ini di atas rata-rata tingkat kemiskinan Nasional yang berkisar 10\%. (Said Ahmad Kabiru, 2017).

Betapa pun pesatnya perubahan Aceh, periode transisi Aceh juga menyisakan sejumlah agenda yang perlu menjadi tantangan bagi pemerintahannya, seperti: penduduk miskin, pengangguran, minimnya lapangan pekerjaan, mahalnya harga barang serta jasa dan lain sebagainya.

Berdasarkan data dari Bank Indonesia, Pertumbuhan ekonomi Aceh secara year on year (yoy) pada triwulan I 2017 mengalami penurunan dibandingkan triwulan pada tahun sebelumnya. Penurunan kinerja ekonomi dari sisi sektoral disebabkan oleh penurunan kinerja sektor utama yakni dari sektor pertanian, perdagangan, konstruksi dan pertambangan. Sementara itu penurunan dari sisi pengeluaran bersumber dari penurunan kinerja komponen konsumsi rumah tangga dan investasi.

Tingkatan inflasi tahunan provinsi Aceh pada akhir triwulan I 2017 tercatat mengalami penurunan, baik dibandingkan inflasi pada tahun 2016, dibandingkan pada periode yang sama di tahun sebelumnya, maupun apabila dibandingkan dengan rata-rata inflasi year on year pada triwulan I dan III (2014-2015). Inflasi tahunan Aceh sepanjang triwulan I 2017 disumbang oleh komoditas oleh kelompok Volatile dan administratered prices.

Kemudian pada triwulan III 2017 pertumbuhan ekonomi di Aceh 


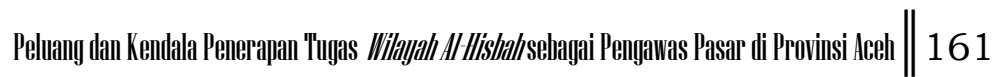

diperkirakan menurun bila dibandingkan triwulan II 2017. Berdasarkan indikator terkini, perekonomian Aceh pada tahun 2017 juga tumbuh lebih rendah dibandingkan tahun 2016. Di sisi lain, pada akhir 2017 inflasi di Aceh berpotensi mengalami peningkatan dibanding tahun 2016. Namun pada triwulan III 2017, tren inflasi Aceh diperkirakan mengalami penurunan dibandingkan triwulan sebelumnya. (Bank Indonesia, 2017)

Walaupun tingkat kemiskinan di Aceh menempati peringkat kelima termiskin di Indonesia, namun hal ini dinilai tak menjadi kendala karena Aceh dinilai memiliki potensi di sektor lain, yaitu pertanian dan perikanan. (https://www.kanalaceh.com/2016/03/1 8/aceh-dinilai-miliki-potensi-sektorpertanian-dan-perikanan/, tanggal 5 Oktober 2017).

Provinsi Nanggroe Aceh Darussalam yang terletak di ujung barat Indonesia, secara geografis di kelilingi oleh laut yaitu Selat Malaka, Samudera Hindia dan pantai utaranya berbatasan dengan Selat Benggala. Wilayah pesisirnya memiliki panjang garis pantai $1.660 \mathrm{~km}$ dengan luas wilayah perairan laut seluas $295.370 \mathrm{~km}^{2}$ terdiri dari laut wilayah (perairan teritorial dan perairan kepulauan) 56.563 $\mathrm{km}^{2}$ dan Zona Ekonomi Eksklusif (ZEE) $238.807 \mathrm{~km}^{2}$. Wilayah pantai dan lautnya secara umum di pengaruhi oleh persimpangan arus dan gerakan Samudera Hindia, Selat Malaka dan Laut Cina Selatan yang berinteraksi dengan daratan pulau Sumatera, Semenanjung Malaka, Kepulauan Andaman dan Nicobar, sehingga menampakkan ekosistem laut di sepanjang pesisir Aceh sangat sesuai bagi kehidupan,biota laut.
Kondisi yang demikian sangat strategis untuk usaha perikanan, khususnya penangkapan ikan di laut dan budidaya tambak. Wilayah pertambakan di sepanjang pesisir Aceh ini sangat didukung oleh luasnya sebaran hutan bakau (mangrove) yang mempunyai fungsi pencegahan abrasi pantai, melindungi habitat biota laut dan pencegahan pencemaran serta memiliki fungsi produksi akuatik yaitu perikanan, tambak dan lain-lain.Di Nanggroe Aceh Darussalam terdapat gugusan pulaupulau besar dan kecil sebanyak 119 buah serta 73 buah sungai penting yang mengalir hingga ke muara.Kondisi wilayah tersebut di atas menjadikan Provinsi Aceh sebagai salah satu wilayah yang memiliki potensi besar di sekitar kelautan dan perikanan. Dengan sentuhan teknologi yang lebih modern dan tepat guna menggantikan teknologi sederhana/tradisional yang masih ada, maka sektor ini mempunyai peluang besar dan dapat menjadi sektor dominan dan andalan untuk mengangkat serta meningkatkan pendapatan (income generating) dan kesejahteraan masyarakat Aceh di masa depan. (Hamdani, https:/ / hamdani75.wordpress.com/2011 /06/21/peluang-dan-tantangan-kelautandan-perikanan-aceh/, diakses tanggal 7 Oktober 2017).

Provinsi Aceh juga memiliki potensi besar di bidang pertanian dan perkebunan. Pertanian di daerah Aceh menghasilkan beras, kedelai, ubi kayu, ubi jalar, jagung, kacang kedelai, sayursayuran, dan buah-buahan. Sedangkan di bidang perkebunan, daerah Aceh menghasilkan coklat, kemiri, karet, kelapa sawit, kelapa, kopi, cengkeh, pala, nilam, 
lada, pinang, tebu, tembakau, dan randu. Dan dari pertanian juga banyak menghasilkan sayur-sayuran dan buahbuahan, seperti bawang merah, cabe, kubis, kentang, kacang panjang, tomat, ketimun, pisang, mangga, rambutan, nangka, durian, jambu biji, pepaya, dan melinjo.( Lembaga Penelitian Sejarah Aceh (LPSA), Potensi Pertanian Aceh, https://lpsa.wordpress.com/2007/11/15 Lpotensi-pertanian-aceh/, diakses tanggal 7 Oktober 2017).

Namun, banyaknya persoalan ekonomi yang dihadapi oleh pemerintah provinsi Aceh, kemudian dengan potensi kekayaan alam yang luar biasa, tentunya bukan sebuah hal yang mudah untuk diselasaikan.

Dalam ajaran Islam, ekonomi dibangun atas dasar agama Islam, karenanya ia merupakan bagian yang tidak terpisahkan (integral) dari agama Islam. Sebagai derivasi dari agama Islam, ekonomi Islam akan mengikuti agama Islam dalam berbagai aspeknya. (Tim Pusat Pengkajian dan Pengembangan Ekonomi, 2008: 13).

Kondisi ekonomi yang mati suri ini tentunya menjadi tantangan bagi pemerintah Aceh untuk melaksanakan berbagai terobosan untuk menguatkan kembali urat nadi perekonomian Aceh sehingga mampu mengurangi angka kemiskinan dan meningkatkan taraf perekonomian masyarakat.

Wilayatul Hisbah sebagai salah satu aparat pemerintahan yang ada di Aceh, jika tugasnya hanya sebatas pengawasan terhadap pelanggaran syariat terkait khalwat, maisir, judi, khamar dan pelanggaran syariat lainnya, tentu ini sangat sempit sekali jika dibandingkan peran dan tugas wilayatul hisbah dalam
Islam. Akan tetapi, jika Qanun tentang tugas Wilayatul Hisbah di Aceh memberikan ruang yang lebih luas terhadap pelaksanaan syariat Islam, hal ini akan sangat berpeluang membantu pemerintah Aceh untuk menyejahterakan perekonomian masyarakat Aceh khususnya.

Berangkat dari permasalahan yang dikemukakan di atas, maka masalah pokok yang menjadi rumusan masalah dalam penelitian ini adalah: Bagaimanakah peluang dan kendala penerapan tugas Wilayatul Hisbah sebagai pengawas pasar di Propinsi Aceh?

\section{METODE PENELITIAN}

Penelitian ini termasuk jenis penelitian kualitatif (naturalistic paradigm). Untuk memperoleh informasi tentang berbagai aspek yang berkaitan dengan persoalan penelitian akan digunakan pendekatan kasus (case approach), yaitu dengan menelaah perundangan yang mengatur tentang pelaksanaan tugas Wilayatul Hisbah di provinsi Aceh seperti disebutkan yang menjadi kajian pokok dalam pendekatan kasus adalah ratio dicedendi (reasoning), yaitu pertimbanganpertimbangan hukum yang digunakan untuk sampai kepada suatu putusan atau kesimpulan. (Peter Mahmud Marzuki, 2008,: 94).

Sumber penelitian ini terbagi dua, yaitu bahan-bahan hukum dan bahanbahan non-hukum. Bahan-bahan hukum juga terbagi dua yaitu bahan-bahan hukum primer yang terdiri dari perundang-undangan yang mengatur tentang pelaksaan peran Wilayatul Hisbah di Aceh dan bahan-bahan hukum sekunder. Bahan-bahan sekunder yang 


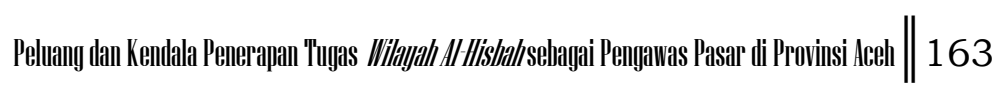

digunakan adalah buku teks tentang kajian Wilayatul Hisbah, baik dalam bentuk buku maupun dalam bentuk jurnal yang relevan dengan persoalan penelitian. (Peter Mahmud: 165)

\section{PEMBAHASAN}

\section{Wilayatul Hisbah}

\section{Pengertian Hisbah}

Hisbah secara etiminologi adalah masdar dari kata kerja hasiba-yahsibu yang berarti menghitung atau mengira. Hisbah juga mempunyai pengertian upah, balasan dan pahala yang diharapkan dari Allah SWT. Disamping itu, hisbah juga berarti pengaturan yang baik. (Abdul Halim Islahi, 1824: 187).

Kemudian secara terminologi, para ulama mempunyai beberapa definisi yang berbeda tentang hisbah, antara lain, yang ditulis oleh Imam al-Ghazali dalam alIhya', bahwa al-hisbah adalah: "Usaha untuk mencegah kemunkaran (pelanggaran) terhadap hak Allah dengan maksud menghindarkan orang yang dicegah dari melakukan kemunkaran".

Selanjutnya Ibnu Khaldun mendefinisikan kalimat hisbah itu dalam Muqaddimah-nya: "Hisbah adalah termasuk kewajiban agama yang dalam kategori amar ma'ruf dan nahi munkar". "Sesungguhnya al-hisbah ialah setiap ma'ruf yang ditinggalkan dan setiap munkar yang dikerjakan". Amar ma' ruf dan nahi munkar adalah kewajiban dari Allah Rabbul Alamin dalam al-Qur'an. Di dalamnya Allah Rabbul Alamin banyak memuji orang yang melakukan amar ma'ruf dan nahi munkar. Bahkan kewajiban ini telah dinyatakan oleh Rasulullah SAW dalam banyak hadistnya. (Muhammad, 2009: 45)

\section{Keutamaan Hisbah}

Secara keseluruhan, Allah Swt memuji dan menyatakan keutamaan orang yang melakukan hisbah dalam firman-Nya:

Artinya: "Tidak ada kebaikan pada kebanyakan bisikan mereka, kecuali orang yang menyuruh mengeluarkan shadaqah atau yang ma'ruf atau perbaikan diantara manusia". (Q.S. An-Nisa' [4] : 14) .

Adapun bagi individu, maka Allah telah menjadikan hisbah sebagai salah satu dari sifat-sifat orang Mukmin. Allah berfirman:

Artinya: "Dan orang-orang Mukmin lakilaki dan perempuan, sebagian dari mereka adalah penolong bagi sebagian yang lain. Mereka menyuruh yang ma'ruf dan mencegah yang munkar, taat kepada Allah dan rasul-Nya. Mereka itulah orang yang akan mendapat rahmat dari Allah. Sesungguhnya Allah Maha Perkasa lagi Bijaksana." (Q.S. At-Taubah [9]: 71).

Adapun orang yang meninggalkan hisbah dan melakukan yang sebaliknya, maka Allah mengutuk dan menyebutnya sebagai munafik, baik laki-laki dan perempuan. Firman Allah:

Artinya: "Orang-orang munafik laki-laki dan perempuan, sebagian mereka adalah penolong sebagian yang lain. Mereka selalu menyerukan yang munkar dan mencegah yang ma' ruf." (Q.S. At-Taubah [9]: 67).

Kemudian Rasulullah Saw juga bersabda:

Dari Abu Sa'id al-Khudri ra berkata, Rasulullah Saw bersabda:"Barangsiapa di antara kamu melihat kemunkaran, maka 
hendaklah ia mengubahnya dengan tangannya. Apabila ia tidak mampu, maka hendaklah ia mengubahnya dengan lisannya. Apabila ia tidak mampu, maka hendaklah ia mengubahnya dengan hatinya. Dan itulah selemah-lemah iman." (H.R. Muslim)

Sedangkan keutamaan hisbah, sebagaimana yang dijelaskan Rasulullah:

Abu Dzar berkata: Beberapa sahabat berkata kepada Rasulullah, "Ya Rasulullah telah berlaku para hartawan dengan pahala (dari Allah), mereka shalat seperti kami, mereka puasa seperti puasa kami, dan mereka bersedekah dengan kelebihan harta mereka. Maka Rasulullah bersabda, "Bukankah Allah telah mengkaruniai kalian dengan suatu yang dapat kalian sedekahkan? Sesungguhnya pada setiap tasbih adalah shadaqah, pada setia takbir adalah shadaqah, pada setiap tahmid adalah shadaqah, pada setiap tahlil adalah shadaqah, menyeru yang ma'ruf adalah shadaqah dan mencegah yang munkar adalah shadaqah". (HR. Muslim).

Dari keutamaan hisbah yang dijelaskan di atas, maka diperlukan para pejuang hisbah yang dengan ketakwaannya dan mujahadahnya (kesungguhannya), melakukan yang ma'ruf dan mencegah yang munkar. Karena umat manusia yang sudah sangat tersesat jadi memerlukan para mujahid yang berkomitmen menegakkan hisbah, agar kehidupan tetap berlangsung. ( $\mathrm{H}$. Kara Muslimin, 2005: 96).

\section{Tujuan Hisbah}

Adapun tujuan utama hisbah adalah: 1. Menjaga agama Allah dengan memastikan bahwa agama Allah dijalankan oleh masyarakat dan dengan menjaga agar tidak diselewengkan agama Allah tersebut.

2. Menyampaikan lingkungan sosial yang condong pada kenajikan dengan terus menerus mendukung standarisasi moral yang tinggi dan tidak mentoleransi tindakan amoral.

3. Menyiapkan manusia agar condong pada kebajikan yang berkaitan dengan kegiatannya dan berusaha untuk berguna bagi lingkungan sosialnya.

4. Membangun sosial lingkungan agar tidak terjadi kejahatan.

5. Mengembangkan, dan menyiapkan standar sosial yang tepat dengan masyarakat agar tidak terjadi kejahatan yang dianggap benar dan sebaliknya.

6. Menjaga agar azab Allah tidak turun pada masyarakat.

7. Meningkatkan status untuk menjadi makhluk yang terbaik di mata Allah. (Zainul Arifin: 2016).

Firman Allah Swt yang tersebut dalam diawal pembahasan ayat 104-105 dalam surat ali-Imran, menyatakan bahwa wajib membentuk satu badan atau lembaga yang melakukan kegiatan dakwah dan memantau perkembangan moral masyarakat. Dalam kaitan dalam moral kita kenal apa yang diperintahkan Allah yaitu "menyuruh melakukan amar ma'ruf dan nahi munkar". Pembentukan hisbah, dimaksudkan sebagai lembaga untuk menyampaikan pandangan, serta saran secara objektif dan independent.

Adapun untuk menjadi anggota badan hisbah, hendaklah orang itu bersikap adil, objektif dan cerdas, serta arif, bijaksana, dia mempunyai pendirian teguh menyangkut pelaksanaan syariat. (Teungku Muhammad Hasbi Ash Shiddiqie, 2000: 347) 


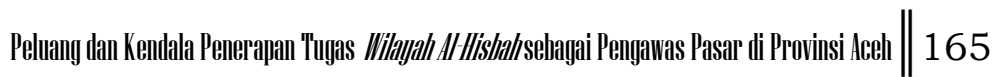

Peran WH (Wilayatul Hisbah) dalam Ekonomi Islam

Lembaga (WH) Wilayatul Hisbah sudah ada sejak masa khalifah Umar Bin Khatab, sedangkan fungsi dan perannya lebih nampak pada masa Bani Umayyah di bawah pimpinan Mu'awiyah bin Abi Sofyan. (Muhammad: 111) Lebih dari satu fakta baik secara tekstual maupun historikal yang menunjukkan institusi hisbah. Alquran sendiri telah menghadirkan satu aturan umum yang memberikan kewajiban pada masyarakat muslim untuk menyuruh pada kebajikan dan melarang kemungkaran. Kewajiban dan perintah ini hendaknya dilakukan oleh pejabat negara yang disebut sebagai muhtasib dan oleh orang-orang yang memiliki kompentensi dari masyarakat umum. (Muhammad, 2009: 64)

Diantara tugas dan tanggung jawab Lembaga Wilayatul Hisbah masa itu antara lain, menjaga harga barang-barang dipasar, memperhatikan kebersihan setiap orang yang diberi tugas memegang suatu jabatan/pekerjaan untuk mengurusi masyarakat seperti tukang pangkas rambut, pembuat roti, penjual makanan dan lain sebagainya. Mereka yang melakukan pekerjaan seperti ini harus mendapatkan izin kerja terlebih dahulu, seperti tes kesehatan. Dan sama sekali tidak dibolehkan bagi orang-orang yang memiliki penyakit tertentu/ cacat jasmani yang berbahaya atau akan menjadi penularan bagi orang lain. (Mustaq Ahmad, 2001: 188).

Menurut istilah wilayatul hisbah yang berdasarkan pada kajian- kajian kitab klasik terutama pada karya Ibnu Taimiyah dan prakteknya pada perekonomian negara Islam pada masa lalu, menjelaskan fungsi umum al hisbah, yaitu: Sebuah sistem yang secara umum digambarkan pelaksanaan kebijakan dan kewajiban oleh mutashabih dan berkaitan dengan aspek agama dan yuridis dalam penguasaannya.

Digambarkan sebagai praktek dan teknik pengawasan secara detail. Pengawasan secara prinsip yang dilakukan atas berbagai bentuk produk kerajinan dan perdagangan, bahkan juga mencakup tatanan administrasi, kualitas dan standar produk.

Adapun fungsinya secara detail adalah:

1. Pengawasan terhadap kecukupan barang dan jasa di pasar. Al-hisbah melalui muhtashibnya harus selalu mengkontrol ketersediaan barang dan jasa yang dibutuhkan masyarakat, misalnya kebutuhan pokok (sandang, pangan, papan, jasa kesehatan, jasa pendidikan, dan lain- lain). Dalam kasus terjadinya kekurangan barangbarang ini mustashib juga memiliki otoritas untuk menyediakan sendiri secara langsung.

2. Pengawasan terhadap industri. Dalam industri ini tugas mustashib adalah pengawasan standar produk, ia juga mempunyai otoritas untuk menjatuhkan sanksi terhadap perusahaan yang terbukti merugikan masyarakat atau negara. Ia juga harus membantu memecahkan perselisihan antara majikan dengan buruh. Jia perlu menetapkan upah minimum.

3. Pengawasan atas jasa. Penipuan dan berbagai ketidak jujuran lainya lebih mudah terjadi di pasar jasa dari pada di pasar barang. Al-mutashib memiliki wewenang untuk mengawasi apakah para penjual jasa seperti dokter, dan 
sebagainya sudah melaksanakan tugasnya secara layak atau belum, pengawasan atas jasa ini juga berlaku atas penjual tingkatan bawah, seperti buruh pabrik dan lain-lain.

4. Pengawasan atas perdagangan, almustashib harus mengevaluasi pasar secara umum dan berbagai praktek dagang yang berbeda-beda secara khusus. Ia harus mengawasi timbangan dan ukuran, kualitas produk, menjamin pedagang dan agennya tidak melakukan kecurangan dan praktik yang merugikan konsumen.

5. Perencanaan dan pengawasan kota dan pasar, al-mustashib berfungsi sebagai pejabat kota untuk menjamin pembangunan rumah atau toko-toko bagi publik.

6. Pengawasan terhadap keseluruhan pasar al-mustashib harus menjamin segala bentuk kebutuhan agar persaingan di dalam pasar dapat berjalan dengan sehat dan islami, misalnya menyediakan informasi yang transparan bagi para pelaku pasar. Menghapus berbagai rektriksi untuk keluar dan masuk pasar, termasuk membongkar berbagai praktek penimbunan. (Muhammad Syarif, t.th.: 2016).

\section{Peran dan Fungsi Hisbah}

Dalam Ensiklopedi Islam, lebih lanjut dijelaskan bahwa melarang kemungkaran meliputi beberapa wewenang di antaranya, pencegahan penipuan di pasar, seperti masalah timbangan, pencengahan, ukuran menjual barang yang telah rusak tetapi tidak diketahui oleh si pembeli, serta mencegah tindakan-tindakan yang merusak moral. Sedangkan memerintahkan kebaikan meliputi hal-hal seperti pemberitahuan masuk waktu shalat, waktu berbuka puasa dan imsak, tidak berbeli, tetapi memerlukan penyelesaian secara cepat dan tidak berkehendak kepada prosedur peradilan biasa. Pada dasarnya dalam ajaran Islam, setiap muslim berkewajiban melaksanakan amar ma'ruf nahi mungkar. Namun melaksanakan amar ma'ruf nahi mungkar dalam masalah tersebut ada suatu badan yang secara khusus menanggulanginya.

Ibnu Kaldum menjelaskan bahwa tugas hisbah yang merupakan tugas keagamaan itu adalah merupakan kewajiban bagi badan yang mengurus kaum muslimin. Diriwayatkan dari Abu Hurairah r.a bahwa Rasulullah Saw pada suatu ketika sedang melihat-lihat suatu tumpukan barang dagangan di pasar, kemudian tiba-tiba Rasulullah memasukkan tangannya ke dalam tumpukan tadi, maka didapatilah bagian bawah dari makanan tersebut dalam keadaan basah. Rasulullah SAW. Bertanya kepada si penjual, "mengapa hal ini bisa terjadi?" si penjual menjawab, "makanan tersebut terkana air hujan ya Rasullah." Rasulullah berkata:

"Apakah tidak sebaiknya kamu letakkan di atas tumpukan makanan yang kamu jual agar di ketahui oleh orang-orang? Barangsiapa yang berlaku tidak jujur bukanlah termasuk golonganku."

Apa yang dilakukan Rasulullah Saw itu tidak lain adalah mencegah seseorang dari melakukan suatu tindakan yang bisa merugikan orang lain atau tidak di sukai Allah Swt. Tindakan yang dilakukan oleh Rasulullah Saw itu dalam terminologi Islam disebut hisbah, sedangkan yang melakukan tindakan itu disebut muhtasib. Tugas hisbah belum secara rsemi 
terbentuk dalam suatu badan. Ia dilembagakan secara resmi pada periode kemudian, di waktu permasalahan kaum muslimin menjadi lebih kompleks. (Ikhwan Hamdani, 2003: 97).

\section{Syarat, Fungsi dan Tugas-tugas Muhtasib (Pelaku Hisbah)}

Syarat Muhtasib

Syarat yang dimaksud adalah sebagai berikut:

1. Seorang muhtasib hendaklah seorang muslim, mardeka, aqil balig, adil, dan memiliki kemampuan profesional.

2. Berilmu pengetahuan tentang hukumhukum syariat Islam, agar mengetahui secara benar apa yang diperintahkan Allah dan dilarang olehnya.

3. Adil, seorang muhtasib berperan sebagai seorang yang dipercaya dan dipatuhi perintahnya, untuk itulah maka dia harus jujur dan adil sebagaimana hal tersebut juga diberlakukan bagi seorang hakim dan penguasa.

4. Seorang muhtasib wajib melaksanakan apa yang diketahui dan diucapkan, tidak bertentangan dengan apa yang di ucapkan.

5. Seorang muhtasib hendaklah berkemampuan (fisik, metal dan ilmu). Untuk memerintahkan kebaikan dan mencegah kemungkaran .

\section{Fungsi dan Tugas-tugas Muhtasib}

Muhtasib juga perlu mengawasi prilaku sosial penduduk kinerja mereka dalam melakukan kewajiban agama dan kerja untuk pemerintah. Secara ringkas dapat di sebutkan fungsi dan tugas-tugas muhtasib sebagai berikut:

1. Memenuhi dan mencakupi kebutuhan;
2. Pengawasan terhadap industri;

3. Pengawasan atas jasa; dan

4. Pengawasan perdagangan.

Dalam menunaikan beberapa kewajibannya, muhtasib dibantu oleh berbagai ahli dari wilayah yang berbeda. Ia juga bisa memperkerjakan sejumlah asisten untuk membantunya dalam menegakkan perintah dan keputusan. (Ikhwan Hamdani, 2003: 97)

\section{Wilayatul Hisbah (WH) di Aceh}

Seiring pemberlakuan undangundang Republik Indonesia Nomor 44 tahun 1999 tentang penyelenggaraan keistimewaan provinsi Daerah Istimewa Aceh dan UU Republik Indonesia Nomor 18 tahun 2001 tentang Otonomi Khusus bagi provinsi Nanggroe Aceh Darussalam serta PERDA Nomor 5 tahun 2000 tentang pelaksanaan Syari'at Islam, maka terbentuklah sebuah lembaga WH yang dikuatkan dengan Qanun Nomor 11 tahun 2004 tentang organisasi dan tata kerja Wilayatul Hisbah yang keberadaannya diharapkan untuk mengawasi pelaksanaan Syari'at Islam di Nanggroe Aceh Darussalam. Di samping itu untuk memperkuat pengawasannya di lapangan, dibentuk pula MuhtasibMuhtasib gampong yang terdiri dari tuhapeut gampong dan tokoh-tokoh muda sebagai Wilayatul Qura yang bekerja secara suka rela ditingkat gampong masing-masing.Lembaga ini diharapkan bisa bekerja mengawasi pelaksanaan Syari'at Islam di tingkat yang paling rendah dan satu hubungan yang bersifat koordinatif, konsultatif dan komunikatif dengan Wilayatul Hisbah (WH) yang bertugas di kecamatan dan kabupaten. 
Di dalam keputusan Gubernur NAD Nomor 01 tahun 2004 tentang kewenangan pembentukan Organisasi WH dijelaskan bahwa tugas WH adalah:

1. Melakukan pengawasan terhadap pelaksanaan dan pelanggaran peraturan perundang-undangan di bidang Syari' at Islam.

2. Melakukan pembinaan dan advokasi spiritual terhadap setiap orang yang berdasarkan bukti permulaan patut diduga telah melakukan pelanggaran terhadap peraturan perundangundangan di bidang syari'at Islam.

3. Menegur menasehati, mencegah dan melarang setiap orang yang patut diduga telah, sedang atau akan melakukan pelanggaran terhadap peraturan perundang-undangan di bidang Syari' at Islam.

4. Melimpahkan perkara pelanggaran peraturan perundang-undangan di bidang Syari'at Islam ke penyidik.

Selanjutnya, berdasarkan Peraturan Gubernur Nomor 47 Tahun 2008 tentang Tugas Pokok dan Fungsi Satuan Polisi Pamong Praja dan Wilayatul Hisbah.

Sekilas, jika dilihat di Aceh antara WH hampir sama dengan Satpol PP. Namun, pada prinsipnya Satpol PP dan WH adalah dua lembaga yang berbeda dasar hukumnya. Satpol PP diatur dalam Peraturan Pemerintah Nomor 32 Tahun 2004. Satuan Polisi Pamong Praja adalah perangkat pemerintah daerah dalam memelihara dan menyelenggarakan ketenteraman dan ketertiban umum serta menegakkan Peraturan Daerah. Sementara WH menurut Qanun No. 11 Tahun 2004 adalah lembaga pembantu tugas kepolisian yang bertugas membina, melakukan advokasi dan melakukan pengawasan amar makruf nahi mungkar dan dapat berfungsi sebagai Polsus (Polisi Khusus) dan PPNS (Penyidik Pegawai Negeri Sipil). Jadi jelaslah secara legal formal dua lembaga ini memiliki payung hukum yang berbeda. Akan tetapi sejalan dengan lahirnya UUPA maka dua lembaga yang berbeda ini di gabung menjadi satu sehingga nomenklaturnya menjadi Satpol PP dan WH. Sebagaimana tertuang dalam Qanun Aceh Nomor 5 Tahun 2007 tentang Susunan Organisasi dan Tata Kerja Satpol PP dan WH.

\section{Peluang dan Kendala Penerapan Tugas Wilayatul Hisbah Sebagai Pengawas Pasar di Aceh}

\section{Peluang WH sebagai Pengawas Pasar di Aceh}

Dalam melakukan aktivitas ekonomi Islam, para pelaku ekonomi memegang teguh prinsip-prinsip dasar yaitu prinsip ilahiyah,dimana dalam ekonomi Islam kepentingan individu dan masyarakat memiliki hubungan yang sangat erat sekali yaitu asas keselarasan, keseimbangan dan bukan persaingan, sehingga tercipta ekonomi yang seadil-adilnya. Kemudian pelaku ekonomi juga harus mengimplementasikan suatu nilai yang menjadi "jantung" dari prinsip-prinsip syariah (tauhid, keadilan, tolong menolong, amanah, saling ridha/'antaradhin, menghindari riba, maisir dan gharar).

Pasar sebagai salah satu tempat berlangsungnya aktifitas ekonomi masyarakat, tidak bisa dihindarkan dari tindakan-tindakan kecurangan dan pelanggaran oleh para pelaku pasar tersebut. Prilaku-prilaku seperti riba, mengurangi takaran atau timbangan, 
penipuan (tadlis), gharar, skandal bisnis, korupsi dan kolusi, monopoli serta penimbunan, menjatuhkan mitra bisnis, dan lain-lain merupakan prilaku-prilaku yang bertentangan dengan ekonomi Islam. Kecurangan dan pelanggaran tersebut menyebabkan terganggunya keseimbangan pasar. Maka salah satu hal yang bisa dilakukan oleh pemerintah untuk menjaga keseimbangan pasar adalah dengan adanya pengawasan pasar oleh pemerintah (wilayatul hisbah). (Syamsul Anwar, 2007: 83)

Begitu juga halnya dengan persoalan ekonomi yang dihadapi oleh pemerintahan Aceh. Terhadap pelanggaran-pelanggaran serta kecurangan-kecurangan yang dilakukan oleh masyarakat dalam bidang perekonomian serta mengelola potensi alam Aceh yang sangat kaya tentunya juga butuh perhatian serta pengawasan yang lebih baik dari pemerintah provinsi Aceh.

Pemberlakuan otonomi khusus untuk provinsi Aceh melalui Undangundang Nomor 22 Tahun 1999 dan Undang-undang Nomor 18 Tahun 2001; kemudian ditindaklanjuti dengan Peraturan Daerah Nomor 5 Tahun 2000 tentang Pelaksanaan Syariat Islam di Propinsi Daerah Istimewa Aceh. Dengan pemberlakuan otonomi khusus untuk Aceh dan diantaranya adalah pemberlakuan syariat Islam, merupakan sebuah keistimewaan yang tidak dimiliki oleh provinsi lain yang ada di Indonesia. Syariat Islam bisa dilaksanakan lebih leluasa dan aman di Aceh karena dipayungi oleh undang-undang pemerintah.

Hal ini juga bisa memberikan peluang dan acuan dasar bagi pelaksanaan tugas Wilayatul Hisbah di
Aceh, dibandingkan yang sudah berlaku saat ini yang hanya sebatas pengawasan terhadap pelanggaran khalwat, maisir khamar dan judi saja. Karena jika mengacu kepada tugas wilayatul hisbah dalam Islam merupakan bingkai pengawasan terhadap seluruh pelanggaran norma-norma agama dan sosial yang berlaku secara baik dalam masyarakat.

Selanjutnya, dengan adanya otonomi khusus pemberlakuan syariat di Aceh, adalah salah satu bukti nyata tingginya tingkat kesadaran beragama di Aceh dalam menjalankan syariat Islam, termasuk persoalan hukum muamalah. Hal ini juga akan memberikan peluang dalam menerapkan tugas $\mathrm{WH}$ sebagai pengawas pasar, diyakini akan mendapat dukungan dari masyarakat Aceh, karena persoalan ekonomi merupakan hal yang bersentuhan langsung dengan kehidupan sehari-hari masyarakat, karena dengan adanya pengawasan pasar oleh $\mathrm{WH}$, akan memberikan rasa aman dan nyaman bagi mereka dalam melakukan aktifitas muamalahnya.

\section{Kendala Penerapan Peran dan Tugas WH Di Aceh Sebagai Pengawas Pasar}

Dalam hal penerapan tugas yang dibebankan kepada WH (Wilayatul Hisbah) sebagai pengawas pasar di Aceh maka tentunya tidak luput dari kendala yang akan dihadapi. Adapun kendala tersebut ialah sebagai berikut:

\section{Keterbatasan Qanun}

Penerapan syariat Islam didasari oleh undang-undang atau qanunqanun sebagai landasan yuridis atau berupa payung hukum untuk pelaksanaannya. Saat ini yang terkait 
dengan tugas pengawasan hanya 5 (lima) qanun yaitu qanun tentang aqidah, ibadah, dan syi'ar, qanun tentang minuman khamar dan sejenisnya, qanun tentang maisir (perjudian), qanun tentang khalwat (mesum), dan qanun tentang pengelolaan zakat. (Arsip Data Kota Lhokseumawe).

Dari beberapa kewenangan yang telah ditetapkan melalui keputusan Gubernur NAD No 01 tahun 2004 tentang kewenangan pembentukan Organisasi WH tersebut dapat dipahami bahwa kewenangan yang ada pada WH sangatlah terbatas terlebih apabila kita melihat harapan dan anggapan masyarakat bahwa $\mathrm{WH}$ berada di garda yag paling depan dan bisa terlibat dalam kasus atau perkara apa saja karena setiap perkara tidak terlepas kaitannya dengan syariat Islam, bahkan tidak jarang WH mendapat ejekan dan cemoohan serta tudingan masyarakat bahwa WH "mandul" dan tidak mampu bekerja sesuai perannya.

Keterbatasan kewenangan tersebut disebabkan personil WH saat ini belum ada yang berstatus Pegawai Negeri Sipil (PNS), apalagi Penyidik Pegawai Negeri Sipil (PPNS) yang secara hukum berfungsi sebagai penyidik dan bisa melakukan sebagian dari tugas-tugas kepolisian umpamanya: menangkap, menggeledah, menyita dan menahan seseorang yang dianggap perlu demi tegaknya peraturan dan perundangundangan. Untuk sementara ini WH tidak bisa melakukan hal-hal semacam itu karena bisa di pra- peradilan kan dengan tuduhan non prosudural. Maka dalam pergerakannya WH saat ini lebih mengarah kepada dakwah-dakwah yaitu mengingatkan masyarakat terhadap peraturan dan perundangundangan di bidang Syariat Islam melalui patroli penyambangan $\mathrm{WH}$ juga terus melakukan sosialisasi melalui media elektronik dengan melakukan dialog di radio-radio, ceramah-ceramah di balai pengajian yang santriwan-santriwatinya dari kalangan remaja serta bekerjasama dengan dinas Pendidikan dan Pengajaran untuk melaksanakan seminar di sekolah-sekolah tingkat menengah (MTsN dan SMP) dan tingkat atas (SMA, SMK dan MAN).

2. Minimnya Pemahaman Hukum Bagi Masyarakat

Masih ada kaum muslim yang merasa tidak suka dengan formalisasi Syari'at Islam dalam peraturan daerah yang mengikat perilaku seluruh warga masyarakat. Dalih yang mereka kemukakan adalah bahwa mereka telah melaksanakan Syariat Islam. Ketidaksukaan sebagian kaum muslim ini, dikarenakan kesalahan dalam memahami syari'at Islam yang dianggap hanya sebatas aturan ibadah ritual, dan mereka merasa sudah menjalankan Ibadan itu sejak kecil. Padahal syariat Islam ádalah kumpulan ketentuan yang mengatur seluruh urusan manusia, baik yang berkaitan dengan hablumminallah maupun hablumminanna. (Zainuddin, Ketua WH Kota Lhokseumawe, wawancara tanggal 23 Juni 2017)

Kendala lain yang dihadapi terhadap penerapan tugas WH di Aceh sebagai pengawas pasar, di samping sampai saat ini masih belum menjadi lembaga yang 
mempunyai instusi yang kuat karena masih memiliki kelemahan di bidang qanun, juga telah ada lembaga pengawasan pasar yang merupakan bagian dari lembaga pemasaran. Kemudian yang menjadi kendala juga terhadap penerapan peran dan tugas $\mathrm{WH}$ di Aceh sebagai pengawas pasar disebabkan dikarenakan gaji yang diperoleh petugas WH di Aceh tidak memadai untuk menghidupi keluarga mereka serta tugas yang dibebankan juga sangat berat, apalagi dengan ditambahnya tugas mereka sebagai pengawas pasar. Ditambah dengan mulai lemahnya dukungan dari berbagai pihak menyebabkan banyak anggota $\mathrm{WH}$ yang keluar dari pekerjaannya. (Zainuddin, 2017)

\section{PENUTUP}

Berdasarkan uraian di atas, tujuan dari hisbah dalam Islam merupakan sarana untuk menyuruh kepada yang ma'ruf dan mencegah kepada yang munkar, artinya mencakup semua persoalan yang berkaitan dengan pengawasan terhadap pelanggaran norma-norma agama dan sosial yang berlaku secara baik dalam masyarakat, termasuk diantaranya pengawasan terhadap pelanggaran-pelanggaran terhadap ketentuan ekonomi Islam oleh para pelaku pasar.

Dengan pemberlakuan Syariat Islam di Aceh, bisa memberikan peluang bagi petugas Wilayatul Hisbah untuk mengontrol dan pengawasi aktifitas ekonomi di pasar, walaupun terdapat banyak kendala dalam penerapannya. Untuk itu diharapkan kepada pemerintah
Aceh untuk merevisi tentang peraturan Qanun terkait pelaksanaan tugas Aparat Wilayatul Hisbah, yang selama ini membatasi tugas mereka yang hanya sebagai pengawas terhadap khalwat, maisir, khamar dan judi saja. Sehingga harapan untuk mewujudkan pelaksanaan syariat Islam secara lebig kaffah termasuk ekonomi Islam bisa terlaksana. Aamiin.

\section{DAFTAR KEPUSTAKAAN}

Ahmad, Muistaq. 2001. Business Ethnic In Islam, Terjemahan Indonesia: Etika Bisnis Islam. Oleh Samson Rohman, Jakarta: Pustaka Al-Kautsar.

Anwar, Syamsul. 2007. Hukum Perjanjian Syariah: Studi tentang Akad dalam Fiqh $M u^{\prime}$ amalah. Jakarta: Rajawali Pers.

Arif, Zainul, Tujuan Hisbah. http:/ / cakzainul.blogspot.com.

Diakses pada Tanggal 20 Juli 2016.

Ash Shiddiqie, Teungku Muhammad Hasbi. 2000. Al-Islam. Semarang: Pustaka Rizki Putra.

Bank Indonesia, Kajian Ekonomi Regional (Provinsi Aceh Mei 2017), 24 Mei 2017

Hamdani, Ihkwan. 2003. Sistem Pasar dan Pengawasan Ekonomi (Hisbah) dalam Perspektif Ekonomi Islam. Jakarta: Nur Insani.

Islahi, Abdul Halim. 1824. Economic Consepts of Ibn Taimiyah. London: The Islamic Fondation.

Muhamad. 2009. Ekonomi Islam. Malang : Empatdua. 
Kabiru Said Ahmad, Perekonomian Aceh 2017, Opini, Serambi Indonesia, 2 Januari 2017

Moleong, Lexy J. 1998. Metodologi Penelitian Kualitatif. Bandung: Remaja Rosdakarya.

Marzuki, Peter Mahmud. 2008. Penelitian Hukum, Kencana Prenada Media Group.

Muhamaad. 2009. Ekonomi Islam, Malang : Empatdua.

Muslimin, H. Kara. 2005. Bank Syariah Indonesia. Yogyakarta: Ekonisia.

Syarif, Muhammad, Mengenal Wilayatul Hisbah, http:/ / muhammadsyrif.com. Diakses pada Tanggal 20 Juli 2016.

Tim Pusat Pengkajian dan Pengembangan Ekonomi Islam. 2008. Ekonomi Islam. Jakarta: PT. Raja Grafindo. https://www.kanalaceh.com/2016/03/18 /aceh-dinilai-miliki-potensi-sektorpertanian-dan-perikanan/

Hamdani, Peluang dan Tantangan Kelautan dan Perikanan di Aceh, https://hamdani75.wordpress.com/ 2011/06/21/peluang-dantantangan-kelautan-dan-perikananaceh/, diakses tanggal 7 Oktober 2017

Lembaga Penelitian Sejarah Aceh (LPSA), Potensi Pertanian Aceh, https://lpsa.wordpress.com/2007/1 1/15/potensi-pertanian-aceh/, diakses tanggal 7 Oktober 2017

Arsip Data WH (Wilayutul Hisbah) Kota Lhokseumawe

Zainuddin, Ketua WH (Wilayatul Hisbah) Kota Lhokseumawe, wawancara tanggal 27 Juni 2017 